\title{
GAMBARAN PENGELOLAAN LIMBAH MEDIS PADAT DI RUMAH SAKIT Hi MUHAMMAD YUSUF KALIBALANGAN KOTABUMI TAHUN 2019
}

\author{
Nova Arisma ${ }^{1 *}$ \\ ${ }^{1}$ Jurusan Kesehatan Lingkungan, Politeknik Kesehatan Tanjungkarang
}

\section{Artikel Info :}

Received 2 Agustus 2021

Accepted 16 Agustus 2021 Available online 31 Agustus 2021

\section{Editor: Mei Ahyanti}

\section{Keyword :}

Solid medical waste, waste management, hospital

\section{Kata kunci :}

Limbah medis padat, pengelolaan limbah, rumah sakit

\begin{abstract}
A bstract
Hi Muhammad Yusuf Hospital produces about $2.4 \mathrm{~kg}$ of solid medical waste per day. The initial survey results found that solid medical waste has not been appropriately managed, even though this waste can be a source of health problems for the community. This study aimed to describe the management of solid medical waste at the Hi Muhammad Yusuf Hospital, Kalibalangan, Kotabumi. This research describes the management of solid medical waste from source, type, weight, sorting, container, collection, and temporary storage. Data were collected through observation and interviews with medical waste management officers. Furthermore, the data is compared with Minister of Health Regulation No. 7 of 2019. Solid medical waste management is declared to meet the requirements if it is following the regulation. The process of sorting, storing, and transporting hospital waste does not meet the requirements. There is still solid medical waste mixed with non-medical waste. Hospitals need to provide medical bags in brown for pharmaceutical waste, red for radioactive waste, and purple for cytotoxic waste. Training for waste management officers is needed to improve understanding of solid medical waste management and the availability of SOPs as a guide for waste management officers.
\end{abstract}

Rumah Sakit Hi Muhammad Yusuf menghasilkan limbah medis padat sekitar 2,4 kg perhari. Hasil survey awal ditemukan bahwa limbah medis padat belum dikelola dengan baik, padahal limbah ini dapat menjadi sumber gangguan kesehatan bagi masyarakat. Tujuan penelitian ini adalah untuk mengetahui gambaran tentang pengelolaan limbah medis padat di Rumah Sakit Hi Muhammad Yusuf Kalibalangan, Kotabumi. Penelitian ini bersifat deskriptif untuk menggambarkan pengelolaan limbah medis padat mulai dari sumber, jenis, berat, pemilahan, pewadahan, pengangkutan, dan penyimpanan sementara. Data dikumpulkan melalui observasi dan wawancara kepada petugas pengelolaan limbah medis. Selanjutnya, data dibandingkan dengan Permenkes No.7 Tahun 2019. Pengelolaan limbah medis padat dinyatakan memenuhi syarat jika sesuai dengan Permenkes. Proses pemilahan, pewadahan dan pengangkutan limbah rumah sakit belum memenuhi syarat. Masih terdapat limbah medis padat yang tercampur dengan limbah non medis. Rumah sakit perlu menyediakan kantong medis berwarna cokelat untuk limbah farmasi, warna merah untuk limbah radioaktif dan warna ungu untuk limbah sitotoksis. Pelatihan bagi petugas pengelola limbah sangat diperlukan untuk meningkatkan pemahaman tentang pengelolaan limbah medis padat serta ketersediaan SOP sebagai arahan bagi petugas pengelola limbah.
Ruwa Jurai: Jurnal
Kesehatan Lingkungan is licensed under a Creative Commons Attribution-NonCommercial 4.0 International License.

Corresponding author: Nova Arisma

J. Lintas Sumatera Kembang Tanjung No 68 Kec. Abung Selatan Kab. Lampung Utara Kecamatan Abung Selatan Kabupaten Lampung Utara

E-mail : Novaarisma31@gmail.com

\section{PENDAHULUAN}

Rumah sakit menghasilkan limbah medis padat yang dapat membahayakan petugas yang menangani limbah tersebut dan pengunjung serta masyarakat sekitar rumah sakit (Aini, 2019). Limbah medis padat rumah sakit dapat mencemari lingkungan dan menimbulkan masalah kesehatan. Hal ini dikarenakan limbah 
medis padat rumah sakit adalah limbah infeksius yang mengandung berbagai mikroorganisme pathogen, bahan kimia beracun dan bendabenda tajam yang dapat menimbulkan gangguan kesehatan dan cidera. Partikel-partikel debu dalam limbah dapat menimbulkan pencemaran udara yang akan menimbulkan penyakit dan mengkontaminasi peralatan medis dan makanan (Fattah, Mallongi, \& Arman, 2007).

Menurut Kementerian Kesehatan RI (2017), disebutkan bahwa jumlah rumah sakit di Indonesia sebanyak 1.090, dengan 121.996 tempat tidur. Hasil kajian terhadap 100 rumah sakit di Pulau Jawa dan Bali menunjukkan bahwa rata-rata produksi limbah sebesar $3,2 \mathrm{~kg}$ per tempat tidur per hari. Analisis lebih jauh menunjukkan produksi limbah (limbah padat) berupa limbah domestik sebesar $76,8 \mathrm{~kg}$ dan berupa limbah infeksius sebesar 23,2 \%. Diperkirakan secara nasional produksi limbah padat rumah sakit sebesar 376.089 ton per hari dan produksi air limbah sebesar $48.985,70$ ton per hari. Jumlah limbah medis padat yang timbul betapa besar potensi rumah sakit untuk mencemari lingkungan dan kemungkinan menimbulkan kecelakaan serta penularan penyakit (Kementerian Kesehatan RI, 2017),

Rumah Sakit $\mathrm{Hi}$ Muhammad Yusuf Kalibalangan Kotabumi merupakan rumah sakit dengan pelayanan kesehatan umum dan spesialis, serta dilengkapi dengan pelayanan penunjang medis 24 jam (RS. Hi. M. Yusuf, 2019). Limbah medis padat yang dihasilkan per hari sekitar 2,1 kg. Hasil studi awal ditemukan bahwa limbah medis padat yang dihasilkan belum dikelola dengan baik, padahal limbah ini dapat menjadi sumber gangguan kesehatan bagi masyarakat. Menurut Peraturan Menteri Kesehatan No.7 Tahun 2019 tentang Persyaratan Kesehatan Lingkungan Rumah Sakit (Kementerian Kesehatan RI, 2019), limbah medis harus dikelola dengan baik agar tidak menimbulkan risiko bagi petugas, pengunjung, masyarakat, dan lingkungan.

\section{METODE}

Penelitian ini bersifat deskriptif untuk menggambarkan pengelolaan limbah medis padat di Rumah Sakit Hi Muhammad Yusuf Kalibalangan Kotabumi. Penelitian dilaksanakan pada bulan April sampai dengan Mei 2019. Objek penelitian adalah pengelolaan limbah medis padat, mulai dari sumber, jenis, berat, pemilahan, pewadahan, penyimpanan, pengangkutan, tempat penampungan sementara.

Data dikumpulkan melalui observasi dari mulai pemilahan, pewadahan (ketersediaan wadah dan konstruksi), waktu penyimpanan, alat pengangkut dan tempat penampungan sementara (lokasi, konstruksi, dan ketersediaan air untuk pencucian tempat penampung). Wawancara dilakukan kepada petugas kebersihan.

Data yang dikumpulkan dibandingkan dengan persyaratan yang ada pada Peraturan Menteri Kesehatan RI Nomor 7 Tahun 2019 (Kementerian Kesehatan RI, 2019), tentang persyaratan kesehatan lingkungan rumah sakit. Pengelolaan limbah medis padat dinyatakan memenuhi syarat jika sesuai dengan persyaratan dan ketentuan tersebut.

\section{HASIL}

Rumah Sakit Hi. Muhammad Yusuf. Rumah Sakit Hi. Muhammad Yusuf merupakan rumah sakit tipe $D$, dengan luas lahan $2.225,00 \mathrm{~m}^{2}$ dan luas bangunan $1.437,59 \mathrm{~m}^{2}$. Jumlah tempat tidur sebanyak 58 TT, dengan rata-rata jumlah pasien rawat jalan sebanyak 24 orang dan pasien rawat inap 32 orang (RS. Hi. M. Yusuf, 2019). Limbah medis padat dihasilkan setiap hari dari ruang rawat inap, rawat jalan, instalasi kebidanan, ruang operasi (OK), unit kamar bayi, unit radiologi, apotek, gudang obat, dan instalasi gawat darurat (IGD).

Tabel 1 menunjukkan jenis limbah medis padat yang dihasilkan pada masing-masing ruangan. Secara umum, jenis limbah medis dari setiap ruangan relatif sama, yaitu botol dan kemasan obat, botol infuse, jarum suntik, kapas, masker, perban, sarung tangan (handscoone), selang infuse, tissue. Hanya ruang radiologi, apotik dan gudang obat yang lebih sedikit, yaitu masker, sarung tangan (handscoone), kemasan obat, dan tissue. 
Tabel 1. Jenis sampah berdasarkan ruangan

\begin{tabular}{ll}
\hline Ruangan & Jenis limbah medis padat \\
\hline Rawat Inap & Botol dan kemasan obat, botol infuse, jarum suntik, kapas, masker, \\
& perban, sarung tangan (handscoone), selang infuse, tissue. \\
Rawat Jalan & Botol dan kemasan obat, jarum suntik, masker, perban, tissue. \\
Instalasi kebidanan dan & Botol dan kemasan obat, botol infuse, jarum suntik, kapas, masker, \\
perawatan bayi & perban, sarung tangan, selang infuse, tissue. \\
Ruang operasi & Botol dan kemasan obat, botol infuse, jarum suntik, kapas, masker, \\
perban, sarung tangan, selang infuse, tissue, topi bedah. & Botol dan kemasan obat, botol infuse, jarum suntik, kapas, masker, \\
IGD & perban, sarung tangan, selang infuse, tissue. \\
Ruang radiologi & Masker, sarung tangan. \\
Apotik dan gudang obat & Kemasan obat-obatan, masker dan tissue. \\
\hline
\end{tabular}

Berdasarkan hasil wawancara dengan petugas kebersihan diketahui bahwa jumlah timbulan limbah medis padat pada bulan Januari - April tahun 2019 sebanyak 104,9 kg, 13,4 kg, 73,2 kg dan $122,1 \mathrm{~kg}$. Pada penelitian ini dilakukan pengukuran berat limbah medis rumah sakit selama tiga hari berturut (tanggal 19-21 Mei 2019), pada pagi hari (pukul 07.00) dan sore hari (pukul 17.00).

Tabel 2. Berat timbulan perhari limbah medis padat di RS

\begin{tabular}{|c|c|c|c|c|c|c|c|}
\hline \multirow{3}{*}{ Sumber } & \multicolumn{6}{|c|}{ Berat perhari $(\mathrm{Kg})$} & \multirow{3}{*}{ Rata-rata } \\
\hline & \multicolumn{2}{|c|}{ Hari 1} & \multicolumn{2}{|l|}{ Hari 2} & \multicolumn{2}{|l|}{ Hari 3} & \\
\hline & 07.00 & 17.00 & 07.00 & 17.00 & 07.00 & 17.00 & \\
\hline Rawat inap & 0,9 & 0,7 & 0,6 & 0,4 & 0,5 & 0,3 & 1,13 \\
\hline Rawat jalan & 0,1 & 0,0 & 0,0 & 0,2 & 0,0 & 0,4 & 0,23 \\
\hline Instalasi kebidanan & 0,4 & 0,2 & 0 & 0,1 & 0,1 & 0,1 & 0,30 \\
\hline Ruang operasi & 0,2 & 0 & 0,1 & 0,2 & 0,2 & 0,2 & 0,23 \\
\hline IGD & 0,2 & 0,0 & 0,2 & 0,2 & 0,4 & 0,1 & 0,36 \\
\hline Apotek & 0,0 & 0,1 & 0,1 & 0,0 & 0,1 & 0,0 & 0,10 \\
\hline Unit radiologi & 0,0 & 0,0 & 0,0 & 0,0 & 0,0 & 0,1 & 0,03 \\
\hline Jumlah & 2,8 & & 2,1 & & 2,3 & & 2,4 \\
\hline
\end{tabular}

Berdasarkan Tabel 2 diketahui bahwa ratarata berat limbah medis padat selama tiga hari pengukuran seberat $2,4 \mathrm{~kg}$, yaitu hari pertama seberat 2,8 kg, hari kedua 2,1 kg, dan hari ketiga $2,3 \mathrm{~kg}$. Berdasarkan sumbernya, limbah medis padat paling banyak dihasilkan dari ruangan rawat inap (rata-rata $=1,13 \mathrm{~kg}$ ), dan paling sedikit dari radiologi (rata-rata $=0,03 \mathrm{~kg}$ ).

Gambar 1 menjelaskan pengelolaan limbah medis padat pada RS. Hi. M. Yusuf, mengacu pada Peraturan Menteri Kesehatan RI Nomor 7 Tahun 2019, tentang persyaratan kesehatan lingkungan rumah sakit. Tahapan pengelolaan yang dilakukan adalah pewadahan limbah medis padat pada setiap ruangan, pengumpulan dari setiap ruangan, penyimpanan sementara, dan pembuangan oleh pihak ketiga.

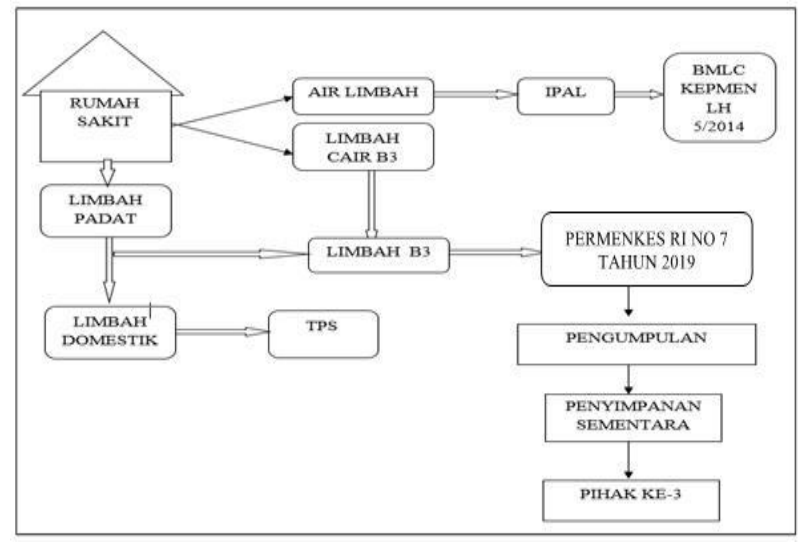

Gambar 1. Alur Pengelolaan Limbah Rumah Sakit

Hasil penelitian mendapatkan bahwa limbah medis padat masih tercampur dengan limbah non medis di beberapa ruangan. Pewadahan limbah medis padat di setiap ruangan penghasil 
limbah diberi kantong plastik limbah medis warna kuning untuk limbah infeksius, farmasi dan patologi, dan warna hitam untuk limbah non medis. Perbedaan warna tersebut untuk memudahkan petugas agar tidak memilah ulang kembali limbah medis padat. Namun, pada kantong plastik tidak diberi label kategori sesuai dengan jenis limbah. Sehingga petugas kesehatan maupun keluarga pasien tidak membuang limbah sesuai wadah yang disiapkan.

Penyimpanan limbah medis padat di tempat pewadahan dan TPS sudah memenuhi syarat karena waktu penyimpanan limbah medis padat di tempat pewadahan 12 jam dan waktu penyimpanan di TPS dalam waktu 90 hari dengan berat limbah medis 2,1 kg perhari sejak limbah dihasilkan.

Pengangkutan limbah medis padat dari setiap ruang tidak menggunakan troli khusus limbah medis yang tertutup. Pengangkutan menggunakan troli limbah domestik dan menggunakan jalur umum.

Berdasarkan hasil pengamatan, TPS sudah memiliki tempat yang permanen, kuat, kedap air dan tahan karat. Namun, lokasi TPS berdekatan dengan ruang rawat inap. Pembersihan TPS dilakukan dua kali seminggu. Pembuangan limbah medis pada dilakukan oleh pihak ketiga, setelah limbah mencapai berat $100 \mathrm{~kg}$.

\section{PEMBAHASAN}

Berdasarkan penelitian, rata-rata berat limbah medis padat yang dihasilkan selama tiga hari pengukuran sebanyak $2,4 \mathrm{~kg}$ per hari. Limbah ditimbang pada pagi hari (pukul 07.00 WIB) untuk mengukur berat limbah yang dihasilkan dari kegiatan rumah sakit sore hingga pagi hari. Penimbangan sore hari pada (pukul 17.00 WIB) untuk mengukur timbulan limbah kegiatan rumah sakit dari pagi hingga sore hari. Limbah medis adalah limbah infeksius, limbah benda tajam, limbah farmasi, dan limbah sitotoksik. Berbagai aktivitas yang dilakukan di rumah sakit dihasilkan limbah bahan yang berbahaya dan beracun yang dapat membahayakan dan menimbulkan gangguan kesehatan bagi pengunjung dan petugas, maka perlu adanya pengelolaan limbah (Widiarti, Simanjuntak, \& Sitorus, 2019).
Dari hasil observasi yang dilakukan di RS Hi Muhammad Yusuf Kalibalangan Kotabumi telah menggunakan alur pengelolaan limbah sesuai peraturan (Gambar 1). Namun, masih ditemukan limbah medis padat dan limbah non medis yang tercampur. Hal ini disebabkan pihak perawat dan pengunjung membuang limbah tidak sesuai tempat setiap jenis limbah, sehingga petugas harus memisahkan kembali antara limbah medis dan limbah non medis yang sudah tercampur. Menurut Kementerian Kesehatan RI (2019), pemilahan adalah proses pemisahan limbah dari sumbernya, pemilahan jenis limbah medis padat mulai dari sumber yang terdiri dari limbah infeksius, limbah patologi, limbah benda tajam, limbah farmasi, limbah sitotoksik, limbah kimiawi, limbah radioaktif, limbah kontainer bertekanan, dan limbah dengan kandungan logam berat.

Pemilahan limbah medis padat berdasarkan jenisnya pada tingkat sumber merupakan tahapan esensial dari pengelolaan limbah medis padat. Pemilahan limbah medis padat yang baik dapat meningkatkan keamanan kerja, serta memperkecil risiko petugas yang menangani limbah dari penularan penyakit. Limbah mengandung bahan berbahaya beracun (B3) yang tidak dikelola akan membahayakan kesehatan masyarakat dan lingkungan hidup (Kementerian LHK, 2018). Limbah non medis rumah sakit dan sampah domestik apabila terkontaminasi limbah medis harus dikelola sebagaimana layaknya limbah medis, maka upaya dini pencegahan kontaminasi limbah medis melalui pemilahan limbah sejak awal dihasilkan harus diprioritaskan (PP No 101 tahun 2014, 2014).

Pemilahan seharusnya dilakukan berdasarkan jenis limbah mulai dari sumber yang menghasilkan limbah medis padat yaitu infeksius dan benda tajam, limbah farmasi, limbah sitotoksik, limbah kimia, limbah radioaktif dan limbah patologi. Sedangkan untuk limbah yang akan dimanfaatkan kembali harus dipisahkan dari limbah yang tidak dimanfaatkan kembali. Sedangkan limbah benda tajam harus dikumpulkan dalam satu wadah yang aman (safety box). Masih ditemukannya limbah padat medis yang tercampur dengan limbah non medis menunjukkan bahwa petugas maupun 
pengunjung belum memahami fungsi pemilahan limbah dan bahaya atau dampak yang ditimbulkan oleh limbah medis padat (Keman \& Triana, 2006; Lagimpe, Miswan, \& Jufri, 2018; Pyopyash, Nurjazuli, \& Yunita, 2019; Sholihah Mar'atus Enny, Sjaaf, \& Djunawan, 2020). Diperlukan upaya meningkatkan pemahaman petugas rumah sakit melalui penyuluhan dan pelatihan.

Pewadahan yang dilakukan pihak rumah sakit sudah cukup baik, karena telah menyediakan dan menggunakan kantong plastik yang sesuai dengan kebutuhannya. Kantong plastik warna kuning untuk semua jenis limbah infeksius, patologi dan anatomi (Andarnita, 2012). Sedangkan kantong plastik warna hitam untuk limbah non medis. Namun, belum dilakukan penyediaan plastik warna merah untuk limbah radioaktif, plastik warna ungu untuk limbah sitotoksis, serta plastik warna coklat untuk limbah kimia dan farmasi. Pada wadah juga tidak terdapat tulisan dan simbol limbah B3 atau limbah infeksius.

Kesalahan pewadahan limbah B3 dan non B3, serta pencampuran limbah obat/farmasi dengan limbah Non B3 tidak sesuai dengan Permen LHK No 56 tahun 2015. Kendala yang ada yaitu kurangnya kesadaran petugas dalam membuang limbah sesuai kategorinya. Belum ada program khusus untuk pemilahan limbah farmasi sehingga pihak sanitasi belum mengajukan pengadaan kantong plastik cokelat (Pertiwi, Joko, \& Dangiran, 2017; Purwanti, 2018; Yolarita \& Kusuma, 2020). Sebaiknya pewadahan harus di tempatkan pada tempat/wadah khusus yang kuat, anti karat, kedap air, terbuat dari bahan yang mudah dibersihkan, dilengkapi penutup, dilengkapi dengan simbol B3, dan diletakkan pada tempat yang jauh dari jangkauan umum. Limbah benda tajam ditempatkan dalam satu wadah (safety box) dan jenis kategori lainnya Menurut (Kementerian Kesehatan RI, 2019), limbah medis padat harus diberi kode warna sesuai kategorinya.

Tempat atau wadah limbah medis padat terbuat dari bahan yang kuat, cukup ringan, tahan karat, kedap air, dan mempunyai permukaan yang halus pada bagian dalamnya, misalnya fiber glass. Pada setiap sumber penghasil limbah medis, harus tersedia tempat pewadahan yang terpisah dengan limbah padat non-medis. Kantong plastik diangkat setiap hari atau kurang sehari apabila 2/3 bagian telah terisi limbah, untuk benda-benda tajam hendaknya ditampung pada tempat khusus (safefy box) (Hasanah \& Oktavianisya, 2018; Ramon, Husin, \& Elianto, 2018; Satiti, Wigati, \& Fatmasari, 2017).

Limbah medis padat sebaiknya tidak diletakkan di tempat penyimpanan terlalu lama karena akan menimbulkan pencemaran. Hasil penelitian mendapatkan bahwa penyimpanan limbah medis padat telah memenuhi syarat, yaitu 12 jam. Penyimpanan limbah medis disesuaikan dengan iklim tropis yaitu pada musim kemarau 24 jam dan musim penghujan 48 jam (Kementerian Kesehatan RI, 2019; Kementerian LHK, 2020). Penyimpanan limbah medis padat di TPS untuk timbulan rata-rata 2,4 $\mathrm{kg}$ per hari sudah memenuhi syarat yaitu $1-3$ bulan. Timbulan limbah $50 \mathrm{~kg} / \mathrm{hari}$ dapat diletakkan di tempat penyimpanan selama 90 hari dan untuk limbah yang dihasilkan kurang dari $50 \mathrm{~kg} /$ perhari dapat diletakkan di tempat penyimpanan selama 180 hari.

Pengangkutan limbah medis padat belum memenuhi syarat. Meskipun petugas pengangkut telah menggunakan APD, namun troli yang digunakan tidak memiliki tutup. Pengangkutan menggunakan troli tertutup bertujuan untuk menghindari gangguan estetika akibat adanya ceceran yang dikhawatirkan kontak dengan manusia (Purwanti, 2018). Petugas selalu mengangkut limbah medis padat $2 / 3$ bagian yang sudah terisi penuh, pengangkutan ini dilakukan pagi dan sore hari dengan menggunakan jalur umum yang dilalui pasien, pengunjung dan petugas rumah sakit lainnya. Pembersihan troli dilakukan setiap selesai pemakaian. Seharusnya, pengangkutan limbah menggunakan troli khusus dengan bahan kedap air, mudah dibersihkan, dilengkapi penutup, tahan karat dan tidak mudah bocor. Pengangkutan limbah harus menggunakan jalur khusus yang jauh dari lalu lintas orang.

Limbah yang terkumpul di tempat penampungan sementara ketika sudah mencapai $100 \mathrm{~kg}$ akan diangkut oleh pihak ketiga yaitu PT Biuteknika Bina Prima. Penampungan sementara (TPS) sudah dibangun dengan dinding dan lantai dari bahan yang kuat, kedap air, mudah dibersihkan, tersedia air kran dan sudah memiliki papan nama TPS. Namun, 
lokasi TPS belum memenuhi syarat karena berdekatan dengan rawat inap, belum tersedia wastafel dengan air yang mengalir dan sabun, tidak terdapat pagar pengamanan area TPS, tidak dilengkapi dengan kotak P3K dan tempat APD. Sebaiknya pihak rumah sakit perlu memperhatikan kondisi TPS agar tidak berdekatan dengan ruang rawat inap, TPS dibersihkan sekurang-kurangnya $1 \times 24$ jam dan disediakan wastafel dan sabun, kotak P3K dan tempat APD (Kementerian Kesehatan RI, 2019).

Dalam pengelolaan limbah di rumah sakit, perlu adanya standar operasional prosedur (SOP) yang jelas (Herman \& Nopriadi, 2020; Zuhriyani, 2019). SOP ini berfungsi sebagai arahan petugas mengelola limbah padat medis agar tidak menimbulkan bahaya bagi petugas maupun lingkungan.

\section{SIMPULAN}

Proses pemilahan, pewadahan dan pengangkutan limbah rumah sakit belum memenuhi syarat. Masih terdapat limbah medis padat yang tercampur dengan limbah non medis. Rumah sakit perlu menyediakan kantong berwarna coklat untuk limbah farmasi, warna merah untuk limbah radioaktif dan warna ungu untuk limbah sitotoksik. Pelatihan bagi petugas pengelola limbah sangat diperlukan untuk meningkatkan pemahaman tentang pengelolaan limbah medis padat serta ketersediaan SOP sebagai arahan bagi petugas pengelola limbah.

\section{DAFTAR PUSTAKA}

Aini, F. (2019). Pengelolaan Sampah Medis Rumah Sakit atau Limbah B3 (Bahan Beracun dan Berbahaya) di Sumatera Barat. Jurnal Education And Development, 7(1), 13-24.

Andarnita, A. (2012). Faktor-faktor yang mempengaruhi Pengelolaan Sampah Medis di Badan LAyanan umum Daerah Rumah Sakit Umum Daerah dr. Zainoel Abidin Banda Aceh Tahun 2012. Jurnal Kesehatan Masyarakat, 16.

Fattah, N., Mallongi, A., \& Arman. (2007). Studi Tentang Pelaksanaan Pengelolaan Sampah Medis Di Rumah Sakit. Makasar: Fakultas kedokteran Universitas Hasanudin.

Hasanah, L., \& Oktavianisya, N. (2018). Gambaran Pengelolaan Limbah Medis Padat pada Pos Kesehatan Desa (Poskesdes) di Kecamatan
Bluto. Gorontalo Journal of Public Health, 1(2), 65. https://doi.org/10.32662/gjph.v1i2.333

Herman, P., \& Nopriadi. (2020). Analisis Pengelolaan Limbah Medis Padat Untuk Mewujudkan. 7(1), 43-52.

Keman, S., \& Triana, N. (2006). Evaluasi

Pengelolaan Sampah Padat di Rumah Sakit Umum Haji Surabaya. Jurnal Kesehatan Lingkungan Unair, 3(1), 3964.

Kementerian Kesehatan RI. (2017). Informasi kesehatan indonesia 2017. In Kementerian Kesehatan RI (Vol. 1).

Kementerian Kesehatan RI. Peraturan Menteri Kesehatan RI Nomor 7 Tahun 2019 Tentang Kesehatan Lingkungan Rumah Sakit. , 26 Kemenkes RI § (2019).

Kementerian LHK. Peraturan Menteri LHK No. 56 tahun 2015 tentang Tata Cara dan Persyaratan Teknis Pengelolaan Limbah Bahan Berbahaya dan Beracun dari Fasilitas Pelayanan Kesehatan. , Biro Hukum KLHK RI § (2015).

Kementerian LHK. (2018). Peta Jalan (Roadmap) Pengelolaan Limbah B3 dari Fasilitas Pelayanan Kesehatan (Fasyankes). KemenLHK, 1-1, 1-2, 322, 3-30.

Kementerian LHK. (2020). Peraturan Menteri Lingkungan Hidup dan Kehutanan Republik Indonesia No

P.12/MENLHK/SETJEN/PLB.3/5/2020 Tentang Penyimpanan Limbah Bahan Berbahaya Dan Beracun. 1-52.

Lagimpe, S. H. A., Miswan, M., \& Jufri, M. (2018). Sistem Pengolahan Sampah Medis Dan Non Medis Di Rumah Sakit Umum Daerah Poso. Jurnal Kolaboratif Sains, 1(1).

Pertiwi, V., Joko, T., \& Dangiran, H. L. (2017). Evaluasi Pengelolaan Limbah Bahan Berbahaya Dan Beracun (B3) Di Rumah Sakit Roemani Muhammadiyah Semarang. Jurnal Kesehatan Masyarakat (e-Journal), 5(3), 420-430.

PP No 101 tahun 2014. Peraturan Pemerintah RI No. 101 Tahun 2014 tentang pengelolaan Limbah Bahan Berbahaya dan Beracun. , (2014).

Purwanti, A. A. (2018). Pengelolaan Limbah Padat Bahan berbahaya dan Beracun (B3) Rumah Sakit di RSUD Dr. Soetomo Surabaya. Jurnal Kesehatan Lingkungan, 10(3), 291-298.

Pyopyash, E. L., Nurjazuli, \& Yunita, N. A. (2019). Kajian Pengelolaan Sampah Medis Di Rumah Sakit X Cilegon. Jurnal Kesehatan Masyarakat (e-Journal), 7(3), 150-155.

Ramon, A., Husin, H., \& Elianto, R. (2018). Analisis Pengelolaan Limbah Medis Padat di Rumah 
Sakit Umum Daerah Kabupaten Mukomuko. Jurnal Ilmiah, 14(3), 1-63.

RS. Hi. M. Yusuf. (2019). Profil Rumah Sakit Hi Muhammad Yusuf Kalibalangan Kotabumi. Kotabumi: RSU. Hi. M. Yusuf.

Satiti, A., Wigati, P., \& Fatmasari, E. (2017). Analisis Penerapan Standard Precautions Dalam Pencegahan Dan Pengendalian Hais (Healthcare Associated Infections) Di Rsud Raa Soewondo Pati. Jurnal Kesehatan Masyarakat Universitas Diponegoro, 5(1), 40-49.

Sholihah Mar'atus Enny, Sjaaf, A. C., \& Djunawan, A. (2020). Evaluasi Pengelolaan Limbah Medis Di Rumah Sakit Sentra Medika Cikarang Medical Waste Management Evaluation at Sentra Medika Hospital Cikarang Health Policy and Administration Postgraduate Program , Department Faculty of Public Health, Universitas Indone. Manajemen Kesehatan, 7(1), 105-114.

Widiarti, W., Simanjuntak, E., \& Sitorus, M. E. (2019). Evaluasi Manajemen Pengelolaan LImbah Medis
Padat Infeksius di Rumah Sakit Umum Deli Serdang Kecamatan Lubuk Pakam Kabupaten Deli Serdang. Journal of Chemical Information and Modeling, 3(3), 2550-0414. https://doi.org/10.1017/CBO9781107415324.00 4

Yolarita, E., \& Kusuma, D. W. (2020). Hospital Medical Waste Management in West Sumatera during COVID-19 Pandemic. Jurnal Ekologi Kesehatan, 19(3), 148-160.

Zuhriyani. (2019). Analisis Sistem Pengelolaan Limbah Medis Padat Berkelanjutan di Rumah Sakit Umum Raden Mattaher Jambi. Jurnal Pembangunan Berkelanjutan, 1.(1), 40-52. 